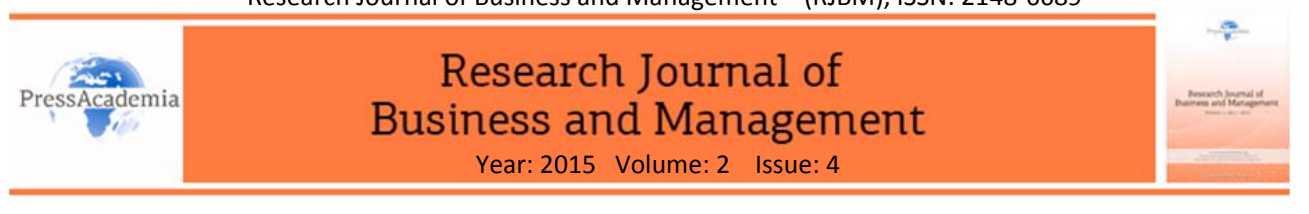

\title{
BUSINESS DEPARTMENTS OF STATE UNIVERSITIES IN TURKEY: LAST FIVE YEARS, CURRENT SITUATION AND FORECASTING FOR THEIR FUTURE
}

DOI: 10.17261/Pressacademia.2015414451

\section{Onder Ziya Paylar', Murat Oturakci}

${ }^{1}$ Mersin University. onder.paylar@yahoo.com

${ }^{2}$ Adana Science and Technology University. moturakci@adanabtu.edu.tr

\section{Keywords}

Business, future of business departments, linear regression model, forecasting, State Universities.

JEL Classification A22, C13,M10

\begin{abstract}
In recent years, when increasing numbers of universities all across the country and accordingly increasing the number of university faculties and departments and rising unemployment rate considered together, a threatening phase will arise about future of some departments in higher education. This future concern has become a common issue intensely in business departments. In the first part of the study, preference percentages, placements of success, minimum and maximum scores and filling rate of quotas in business departments of state universities between 2010 - 2014 are analyzed. According to last five years of business departments are examined and suggestions have been developed with predictions for its future. Second part of the study contains forecasting for business department using the first part's parameters which are preference percentages, placements of success, minimum and maximum scores and filling rate of quotas. Linear regression model has been applied as a forecasting method for the study and those results have been compared with actual data. Ultimately, future of business department, which should be highly favorable, will be displayed and necessary precautions have been mentioned which have to be done immediately.
\end{abstract}

\section{TÜRKIYE'DEKI DEVLET ÜNIVERSITELERININ IŞLETME BÖLÜMLERI: SON BEŞ YILI, MEVCUT DURUMU VE GELECEĞINE YÖNELIK TAHMINLEME} ÇALIŞMASI

\section{Anahtar Kelimeler İşletme, İşletme Bölümünün Geleceği, Doğrusal Regresyon, Tahminleme, Devlet Üniversiteleri}

JEL Sınıflandırması A22, C13, M10

\section{ÖZET}

Son yıllarda ülke genelinde artan üniversite ve buna bağlı olarak artan fakülte ve bölüm sayıları ile gün be gün artan işsizlik oranı birlikte değerlendirildiğinde yükseköğretim bazında bazı bölümlerin geleceği konusunda endişe verici bir boyut ortaya çıkmaktadır. Sözü edilen bu gelecek kaygısı yoğun olarak iş̧letme bölümünde de rastlanır hale gelmiştir. Bu çalışmanın ilk aşamasında Türkiye'deki devlet üniversitelerinde bulunan İşletme bölümlerinin 2010 - 2014 yılları arasındaki tercih edilme yüzdeleri, başarı sıraları, tavan ve taban puanları ile belirlenen kontenjanların doluluk oranları incelenmiştir. Buradan hareketle isşletme bölümünün son beş yıl içerisindeki durumu incelenmiş ve geleceğine yönelik öngörülerde bulunularak öneriler geliştirilmiştir. Çalışmanın ikinci aşaması ise İşletme bölümünün, ilk aşamadaki parametreler (tercih edilme yüzdeleri, başarı sıraları, tavan ve taban puanları, belirlenen kontenjanların doluluk oranları) açısından gelecekteki durumunun tahmin edilmesini kapsamaktadır. Çalışma kapsamında Doğrusal Regresyon yöntemi kullanılarak belirtilen tahminleme ișlemi gerçekleştirilmiş ve bu tahminleme sonuçları gerçek verilerle karşılaştıııımıştır. Bu çalışmanın sonucunda yüksek tercih edilme potansiyeline sahip olması gereken İ̧̧letme bölümünün gelecekte konumunun ne olacağı gözler önüne serilerek gerekli önlemlerin ivedilikle alınması konusunda vurgular yapılmıştır. 


\section{GiRiş}

Ülkemizde her yıl üniversite ve buna bağı olarak fakülte ve bölüm sayılarında artış gözlenmektedir. 1982 'de 27 olan üniversite sayısının son yıllarda yeni açılan devlet ve vakıf üniversiteleri ile birlikte 2014 yılında 176'ya ulaştığı, bu sayıya vakıflara meslek yüksekokulları da dahil edildiğinde sayının 184'e vardığı gözlenmektedir (Çetinsaya, 2014). Aynı artış üniversitelere yerleşen öğrenci sayılarında da mevcuttur. 1982 yılında yükseköğrenim gören öğrenci sayısı 281.539 iken bu sayı her yıl hızla artmaya devam etmiş ve Nisan 2014 itibarıyla yaklaşık olarak 5,5 milyona ulaşmıştır (Çetinsaya, 2014). Bu sayısal verilerden hareketle açılan üniversite sayısı ile doğru orantılı olarak ülke genelindeki İşletme bölümü sayısı ve bu bölüme yerleşen öğrenci sayıların da yıl bazında ciddi miktarda artış olduğu söylenebilmektedir. Ancak sayıca artan bu üniversitelerdeki iş̧letme bölümlerini tercih eden üniversite adaylarının karakteristiğinde her yıl faklılaşan bir durum gözlenmektedir. Bu farklılaşma, İşletme bölümüne öğrencilerin giderek daha düşük puan ve başarı sıralamasıyla yerleşmesi şeklinde özetlenebilmektedir.

Çalışma iki aşamadan oluşmaktadır. İlk aşama Türkiye'deki devlet üniversitelerinin İşletme bölümlerinin son beş yıl içerisindeki tercih edilme durumunu, tercih eden adayların başarı sıralamaları ve puan durumlarını ortaya koymayı amaçlamaktadır. İkinci aşama ise aynı parametreler üzerinden bir sonraki yıla yönelik tahminleme çalışmasının gerçekleştirilmesidir. Çalışmanın sonuç kısmında ise tahminlenen değerler gerçek verilerle karşılaştırılmış ve İşletme bölümünün geleceğine yönelik önerilere yer verilmiştir.

\section{LITERATÜR ARAŞTIRMASI}

Çalışma, Türkiye'deki devlet üniversitelerinde eğitim - öğretim hizmeti veren İşletme bölümlerinin 2010 - 2014 yılları arasındaki son beş yıllık periyodunu incelemektedir. Türkiye'deki vakıf üniversitelerinin aynı bölüm içerisinde farklı bursluluk oranları ve bu oranlara göre değişkenlik gösteren tavan ve taban puanları nedeniyle çalışma yalnızca devlet üniversiteleri üzerinde yoğunlaşmıştır.

Türkiye'de İşletme eğitimi Osmanlı İmparatorluğu dönemine kadar uzanmakla birlikte bu alandaki eğitimin başlangıcı 1882 yılında kurulan Yüksek Ticaret Okulu olarak kabul edilmektedir (Sargut, 2009). Bulundukları üniversitelerin birçoğunda İşletme bölümleri en eski bölümler kategorisinde yerini almaktadır (Yelkikalan ve Pazarcık, 2005). Bu durumdan yola çıkarak İşletme bölümünün öneminin bir kez daha ortaya çıktığı söylenebilmektedir. Erdoğan (1998)'e göre; Türkiye'de mevcut işletme bölümleri, kamu kurumlarında, kar amacı gütmeyen kuruluşlarda ve özel sektörde satıştan muhasebeye, günümüz adıyla insan kaynakları olan personel memurluğundan bölüm şefliklerine ve daha üst konumlardaki görevlere kadar farklı birimlere personel yetiştirmektedir (Düzakın ve Yılmaz, 2009).

İş pazarında kamu sektörünün önemli bir rakibi haline gelmeye başlayan özel sektör İşletme bölümünün ürün ve süreçleri üzerinde etki sahibi olmaya başlamıştır (Sargut, 2009). Buradan hareketle İşletme bölümünün Türkiye'deki gerek kamu gerekse özel sektörü kapsayan iş hayatı bakımından da öneminin büyük olduğu sonucuna varılabilir. Gerek üniversitelerdeki en eski bölümler konumunda olması dolayısıyla üniversitelerin Türkiye'deki durumunu örnekleyebilmesi, gerekse iş hayatında nitelik bakımından zenginlik gerektiren pozisyonlarda görevlendirilecek personellerin yetiştirildiği bölümler 
olması bakımından İşletme bölümünde ortaya çıkacak herhangi bir değer kaybı, Türkiye açısından önemli derecede olumsuz sonuçlara sebebiyet verebilecektir. Benzer bir görüşe göre, yoğun bir rekabet ortamının gözlendiği günümüz küresel pazarında piyasanın beklentileri ve gereksinimlerini karşılayabilen personellerin yetiştirilmesi önemli bir konu haline gelmiş olup bu konuda üniversitelerin başarısızlığının ve potansiyel personellerin kalitesizliğinin maliyeti tüm toplumu etkileyebilecek düzeylere ulaşmıştır (Patır ve Yıldız, 2008). Çalışmada ortaya çıkarılması beklenen İşletme bölümünün öncelikli tercih edilirliğindeki düşüş ve bölümün gelecek yıllarına yönelik tahminleme, ülke açısından bu denli öneme sahip İşletme bölümünün güncel durumunun ve geleceğinin geniş bir açıdan incelenmesine olanak tanıyacaktır. Çalışma, sözü edilen mevcut durum ve tahminleme konusunda ortaya koyacağı sonuçlar bakımından önem taşımaktadır.

\section{ARAŞTIRMA METODOLOJISI}

Araştırma modeli öncelikle tarama modeli olarak seçilmiştir. Ülkemizde Öğrenci Seçme ve Yerleştirme Merkezi (ÖSYM) tarafından alınan bir karar ile 2010 yılından beri çift aşamalı sınav sistemi uygulanmaktadır. Değişen sınav sistemi ile birlikte sınav müfredatında ekleme ve çıkarmalar yapılmış, katsayılarda değişikliğe gidilmiş ve puan hesaplama oranlarında ciddi farklılıklar yapılmasına karar verilmiştir. Yapılan değişiklikler doğrultusunda 2010 yılından önce yapılan sınav sonuçlarına göre sıralamalarda ve puanlarda belirgin farklar ortaya çıkmıştır. Bu sebeple bu çalışmada son beş yıldaki (2010 2014) sınav sonuç kılavuzları taranarak Türkiye'deki devlet üniversitelerinde bulunan İşletme bölümlerinin 2010 - 2014 yılları arasındaki tercih edilme yüzdeleri, başarı sıraları, tavan ve taban puanları ile belirlenen kontenjanların doluluk oranları bilgileri çıkarılmış grafiklerle görselleştirilerek analiz edilmiştir. Çalışmanın bir sonraki aşamasında ise doğrusal regresyon yöntemi kullanılarak 2015 yılı için minimum ve maksimum başarı sıralamaları, taban ve tavan puanları ve kontenjanlarla ilgili tahminleme yapılmıştır. Çalışmanın ilk kısmını oluşturan taramalar ÖSYM'nin sınav sonuç kılavuzları kısmından alınarak Microsoft Excel 2010' a aktarılıp çözümlenmiştir. Tahminleme ise IBM SPSS Statistic 21 programı aracılığıyla yapılmıştır.

\section{VERI ANALIZI VE BULGULAR}

2010 - 2014 yılları arasındaki veriler doğrultusunda yapılan analiz ve bu analizden yola çıkılarak yapılan tahminleme çalışmasına ait sonuçlar bu bölümde açıklanmıştır.

Tablo 1: 2010 - 2014 Yılları Arası İşletme Bölümü Kontenjan ve Bölüme Yerleşme Bilgileri

\begin{tabular}{|l|r|r|r|r|r|r|r|}
\hline Yıl & \multicolumn{1}{|c|}{$\begin{array}{c}\text { Taban } \\
\text { Puanı }\end{array}$} & Tavan Puan & Kontenjan & Yerleşen & $\begin{array}{r}\text { Minimum } \\
\text { Sıra }\end{array}$ & $\begin{array}{c}\text { Maximum } \\
\text { Sıra }\end{array}$ & $\begin{array}{c}\text { Doluluk } \\
\text { Oranı }\end{array}$ \\
\hline $\mathbf{2 0 1 0}$ & 267,22 & 565,78 & 14847 & 14847 & 1030 & 462000 & $100,00 \%$ \\
\hline $\mathbf{2 0 1 1}$ & 269,14 & 575,88 & 15987 & 15987 & 1110 & 380000 & $100,00 \%$ \\
\hline $\mathbf{2 0 1 2}$ & 230,63 & 543,69 & 17825 & 17825 & 1190 & 359000 & $100,00 \%$ \\
\hline $\mathbf{2 0 1 3}$ & 196,40 & 534,85 & 18725 & 18207 & 1660 & 411000 & $97,23 \%$ \\
\hline $\mathbf{2 0 1 4}$ & 197,31 & 544,50 & 18748 & 18229 & 1410 & 437000 & $97,23 \%$ \\
\hline Ortalama & 232,14 & 552,94 & 17226 & 17019 & 1280 & 409800 & $98,89 \%$ \\
\hline
\end{tabular}


Tablo 1'de görüldüğü üzere, Türkiye'deki devlet üniversitelerinin İşletme bölümüne son olarak 267,218 taban puanına sahip aday yerleşmiş ve ülke genelinde açılan kontenjanın tamamı dolmuştur. 2014 yılına gelindiğinde ise bölüme son olarak 197,309 taban puanına sahip aday yerleşmiş ve ülke genelinde açılan kontenjanın yalnızca \% 97'si dolmuştur.

Şekil 1: 2010 - 2014 Yılları Arası Taban ve Tavan Puan Değişimi

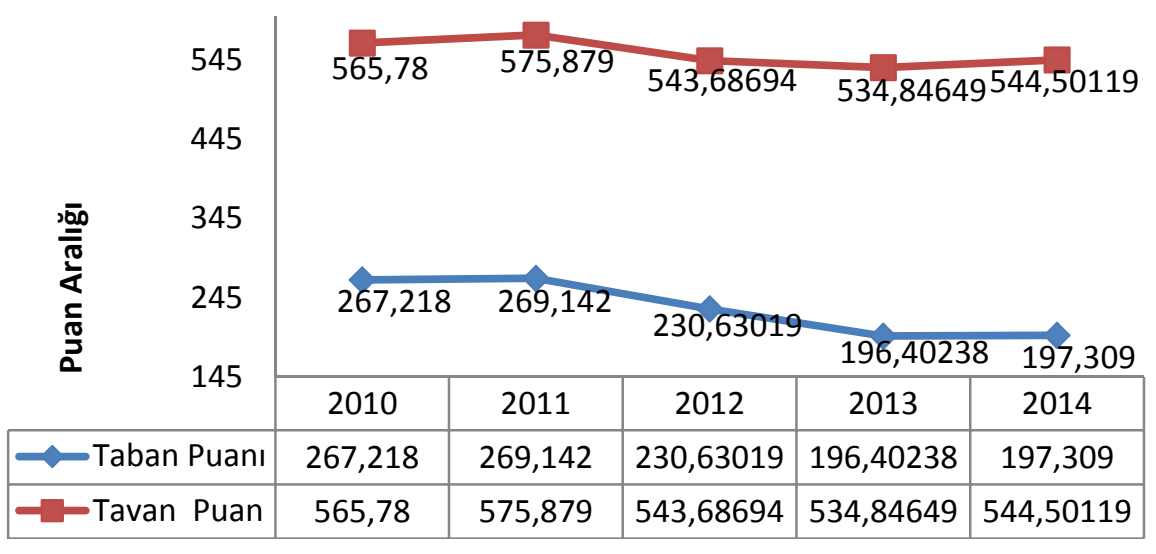

Şekil 1'den görüldüğü üzere 2010 - 2014 yılları arasında Iş̧letme bölümüne en yüksek ve en düşük puanla yerleşen üniversite adaylarının aldıkları puanlarda düşüş yaşanmıştır. Bu düşüş bölümün tavan puanına kıyasla taban puanında daha net ortaya çıkmış ve 2010 ile 2014 yılları arasındaki puan farkı daha belirgin hale gelmiştir.

\section{Şekil 2: 2010 - 2014 Yılları Arası Kontenjan ve Yerleşen Aday Sayıları Değişimi}

\begin{tabular}{|c|c|c|c|c|c|}
\hline \multirow[t]{2}{*}{$\begin{array}{l}20000 \\
19000 \\
18000 \\
17000 \\
16000 \\
15000 \\
14000 \\
13000\end{array}$} & \multicolumn{2}{|c|}{14847} & & $\begin{array}{r}18725 \\
1820\end{array}$ & $\begin{array}{c}18748 \\
18229\end{array}$ \\
\hline & 2010 & 2011 & 2012 & 2013 & 2014 \\
\hline Kontenjan & 14847 & 15987 & 17825 & 18725 & 18748 \\
\hline -Yerleşen & 14847 & 15987 & 17825 & 18207 & 18229 \\
\hline
\end{tabular}

Şekil 2'de 2010 - 2014 yılları arasında ülke genelinde İşletme bölümü için açılan kontenjanlar ve bu kontenjanların doluluk oranlarına ait yıl bazında değişimler gösterilmiştir. Şekilden de görüldüğü üzere bu beş yıllık periyotta her yıl bölüm için ayrılan kontenjanlarda artış gözlenmiştir. 2010'dan 2012'ye kadar açılan kontenjanlar \% 100 doluluk göstermişken, 2013 yılından itibaren kontenjanların düşen taban puanlara rağmen dolmadığı ortaya çıkmaktadır. Bu durum da tahiminleme çalışması açısından önem taşımaktadır. 
2010 yılından sonra ÖSYM'nin yaptığı iki aşamalı sınavlar ile dört yıllık bir bölüme yerleşebilmek için üniversite adayları öncelikle ilk basamak olarak adlandırılan Yükseköğretime Geçiş Sınavı'na (YGS) girmelidir. YGS'de bir öğrenci 180 puan barajını geçebilirse ikinci basamak sınavı olarak adlandırılan Lisans Yerleştirme Sınavı'na (LYS) girmeye hak kazanacaktır. LYS beş ayrı kategoride düzenlenmiş olup, adaylar tercih etmek istedikleri bölümlere göre bu sınavlara girmek zorundadırlar. İşletme bölümlerinin tercih edilebilmesi için bir öğrenci LYS grubundan LYS-1 (Matematik-Geometri) ve LYS-3 (Edebiyat - Coğrafya 1) grubundan sınava girip TM-1 puanı olarak adlandırılan puan türünden ham puan olarak yine YGS' deki gibi 180 puanı aşmak zorundadır. Kısaca işletme bölümünü tercih etmek isteyen bir adayın, TM-1 puanının hesaplanabilmesi için sırasıyla YGS, LYS-1 ve LYS-3 sınavlarına girip 180 barajını geçmesi gerekmektedir.

TM-1 ham puanı 180 puanın üzerinde olan adayın işletme bölümünü tercih edebilmesi için bir engeli yoktur. Aday yerleşme puanı üzerinden (Y-TM1) tercihini yapabilir. Y-TM1 puanı ise adayın aldığı ham puanın üzerine eklenen okul başarı puanı ile hesaplanır. Okul başarı puanları ÖSYM'nin yaptığı hesaplamalar ile 250 - 500 puan arasında olup, bu puanın 0,12 katsayısı ile çarpılması ile elde edilir. Yani okul başarı puanı en düşük 30, en yüksek 60 puan olarak hesaplanabilmektedir.

Buradan hareketle dört yıllık herhangi bir bölüme girmek isteyen bir adayın yerleştirme puanının minimum 210 puan olabileceği aşikârdır (180 ham puan + en düşük okul puanı olan 30). ÖSYM'nin son dönemde aldığı kararlar ile alan dışı bölüm tercih etmede yarı yarıya düşürülen okul başarı puanları uygulaması iptal edilmiştir. Okul başarı puanının yarıya düşmesi ancak ve ancak adayın bir önceki senede bir yükseköğretim programına yerleştiği halde tekrar sınava girip tercih yapması durumunda ortaya çıkmaktadır. Böylesi bir durumda bir adayın minimum 195 yerleştirme puanı olacaktır (180 ham puan + 15 en düşük okul puanının yarısı). Tablo 1'de gösterilen bilgilerin ışığında 2010 - 2012 yılları arasında İşletme bölümlerinin taban puanları, yerleştirme işlemi için gerekli 195 puanın bir hayli üzerindedir. 2013 yılından itibaren taban puanların 196 - 197 seviyesine kadar düştüğü görülmektedir ki bu durum, bir önceki senede üniversiteye yerleşen bir adayın minimum yeterli puanları alması halinde bile İşletme bölümlerinden birine yerleşebildiğini göstermektedir. Bununla birlikte kontenjanlarda hala boşluk görülmekte olup, 195 puan alan bir adayın tercih etmesi halinde boş kalan kontenjanlara girebileceği açıktır. Kontenjanların giderek artmasının sebep olduğu düşünülen bu durumun ilerideki senelerde de devam edeceği öngörülmekte olup tahminleme kısmında bu öngörü sayısal olarak ifade edilmiştir. 
Tablo 2: Tahminlemede Kullanılan Değişkenlere Ait Katsayılar

\begin{tabular}{|l|l|l|l|l|l|l|}
\hline \multicolumn{7}{|c|}{ Tahmin Katsayıları } \\
\hline Sabit & $\begin{array}{l}\text { Taban } \\
\text { Puanı }\end{array}$ & $\begin{array}{l}\text { Tavan } \\
\text { Puanı }\end{array}$ & Kontenjan & Yerleşen & $\begin{array}{l}\text { Minimum } \\
\text { Sıra }\end{array}$ & $\begin{array}{l}\text { Maximum } \\
\text { Sıra }\end{array}$ \\
\hline 271,586 & Tahminlenen & 0,391 & $-0,016$ & 0,000 & $-0,012$ & 0,000 \\
\hline$-2047,259$ & 3,794 & Tahminlenen & 0,000 & 0,069 & 0,088 & 0,001 \\
\hline$-9234,445$ & 0,000 & 7,959 & Tahminlenen & 1,152 & 0,710 & 0,004 \\
\hline 8018,015 & 0,000 & $-6,911$ & 0,868 & Tahminlenen & $-0,617$ & $-0,003$ \\
\hline 23372,171 & $-43,308$ & 11,416 & 0,000 & $-0,797$ & Tahminlenen & $-0,012$ \\
\hline 2002773,506 & $-3711,045$ & 978,270 & 0,000 & $-68,319$ & $-85,691$ & Tahminlenen \\
\hline
\end{tabular}

Tablo 2'de İşletme bölümüne yönelik gelecek yıllar için yapılacak olan tahminleme çalışmasında, her bir değişkenin tahmin denklemindeki katsayıları verilmiştir.

Tablo 3: 2015 Tahminleme Denklemleri

\begin{tabular}{|l|}
\hline Tahminleme Denklemleri \\
\hline 2015 Taban Puanı $=271,586+($ TavanPuan*0,391) $-($ Kontenjan*0,016)-(Min.Sıra*0,012) \\
\hline 2015 Tavan Puan $=-2047,259+($ Taban Puan*3,794)+(Yerlesen*0,069)+(Min.Sıra*0,088)+(Max.Sıra*0,001) \\
\hline 2015 Kontenjan $=-9234,445+($ Yerlesen*1,152)+(Min.Sıra*0,710)+(Max.Sıra*0,004)+(TavanPuan*7,959) \\
\hline 2015 Yerlesen $=8018,015-($ Min.Sıra*0,617)-(Max.Sıra*0,003)-(TavanPuan*6,911)+(Kontenjan*0,868) \\
\hline 2015 Minimum Sıra = 23372,171-(TabanPuan*43,308)-(Max.Sıra*0,012)+(TavanPuan*11,416)-(Yerlesen*0,797) \\
\hline $\begin{array}{l}2015 \quad \text { Maximum Sıra }=2002773,506-(T a b a n P u a n * 3711,045)+(T a v a n P u a n * 978,270)-(Y e r l e s e n * 68,319)- \\
\text { (Min.Sıra*85,691) }\end{array}$ \\
\hline
\end{tabular}

Tablo 3'te 2015 yılı için İşletme bölümüne ait taban ve tavan puanları, açılacak kontenjan sayısı, bu kontenjanlara yerleşecek aday sayısı ve bu adaylara ait minimum ve maksimum sıraların tahminleme denklemleri verilmiştir.

Tablo 4: 2015 Yılı Tahminleme Sonuçları

\begin{tabular}{|l|l|l|l|l|l|l|}
\cline { 2 - 7 } \multicolumn{1}{c|}{} & Taban Puanı & Tavan Puan & Kontenjan & Yerleşen & Minimum Sıra & Maximum Sıra \\
\hline 2015 Yılı Tahmini & 189,31 & 552,94 & 19723 & 19075 & 1661 & 409800 \\
\hline Üst Sınırı & 222,09 & 600,53 & 22108 & 21650 & 2312 & 525405 \\
\hline Alt Sınırı & 116,53 & 505,35 & 17339 & 16499 & 1011 & 294195 \\
\hline
\end{tabular}

Tablo 2'de verilen katsayılar aracılığıyla oluşturulmuş, Tablo 3'te verilmiş olan tahminleme denklemleri aracılığıyla tüm değişkenler için 2015 yıllarına ait tahminleme yapılmış ve sonuçlar Tablo 4'te gösterilmiştir. Tablo 4'ten görüldüğü üzere geçmiş yıllardaki düşüşün 
2015 yılında da devam ettiği söylenebilmektedir. Kontenjan doluluk oranının daha da düşen puan tahminine rağmen \% 96'lara kadar gerileyeceği öngörülmektedir. Daha önceki kısımlarda belirtildiği üzere herhangi bir bölümü tercih edebilmesi yani puanının hesaplanması için adayın alması gereken minimum yerleştirme puanı 195'tir (180 ham puan +15 en düşük okul puanının yarısı). Bu yüzden 2015 yılı taban puan tahmininin tabloda 189,3118 olarak görülmesine rağmen bu durum matematiksel olarak mümkün olmamakta, dolayısıyla gerçekte bu puan hesaplanabilen minimum yerleştirme puanı olan 195 olarak değerlendirilmelidir. Buradan hareketle 180 barajını aşmış ve bir önceki sene herhangi bir yükseköğretim programına yerleşmiş, en düşük okul başarı puanının yarısına sahip adayın bile herhangi bir İşletme bölümüne yerleşebileceği öngörülmektedir.

Tablo 5: 2010 - 2014 Yılları Arası YGS ve LYS Türkiye Net Ortalamaları

\begin{tabular}{|c|c|c|c|c|c|c|c|c|c|}
\hline & & \multicolumn{4}{|c|}{ YGS } & \multicolumn{4}{|c|}{ LYS1/LYS3 } \\
\hline & & Türkçe & $\begin{array}{l}\text { Sosyal } \\
\text { bilimler }\end{array}$ & Matematik & $\begin{array}{l}\text { Fen } \\
\text { Bilimleri }\end{array}$ & Matematik & Geometri & Edebiyat & $\begin{array}{l}\text { Coğrafya } \\
1\end{array}$ \\
\hline & Soru Sayısı & 40 & 40 & 40 & 40 & 50 & 30 & 56 & 24 \\
\hline \multirow{6}{*}{$\frac{\bar{c}}{\overline{\bar{\nu}}}$} & 2010 & 21,6 & 12,4 & 11,9 & 5,5 & 14,7 & 10,8 & 27,8 & 10,1 \\
\hline & 2011 & 21,8 & 11,3 & 7,8 & 4,9 & 15,93 & 9,05 & 21,54 & 9,36 \\
\hline & 2012 & 18,02 & 11,3 & 7,27 & 4,43 & 14,43 & 7,52 & 24,08 & 7,58 \\
\hline & 2013 & 16,8 & 12,1 & 7,5 & 3,5 & 12,32 & 4,15 & 23,22 & 7,61 \\
\hline & 2014 & 19 & 10,9 & 6,5 & 4,5 & 10,58 & 6,02 & 19,22 & 8,59 \\
\hline & Ortalama & 19,444 & 11,6 & 8,194 & 4,57 & 13,59 & 7,51 & 23,17 & 8,64 \\
\hline
\end{tabular}

Tablo 5, 2010 - 2014 yılları arasında İşletme bölümlerini tercih edebilmek için girilen YGS, LYS-1 ve LYS-3 sınavlarındaki test gruplarının ortalama net dağılımlarını göstermektedir. 2015 yılında yapılacak sınavlarda İşletme bölümünü tercih etmek isteyen bir üniversite adayının, son beş yıldaki ortalama sayıdaki netleri yaptığı varsayılırsa, bu adayın yaklaşık TM-1 puanı 227 - 228 düzeyinde olacaktır. Bu adayın en düşük okul başarı puanına sahip olduğu (30 puan) ve bir önceki sene bir yükseköğretim kurumuna yerleşmediği öngörülürse, Y-TM1 puanının 257 - 258 düzeyinde olacağı hesaplanır. Bu yerleştirme puanı ile adayın Marmara ve Güneydoğu Anadolu Bölgeleri'nde bilinen ve bazı köklü üniversitelerin İşletme bölümlerine girebileceği öngörülmektedir. Yine aynı adayın bir önceki yıl bir yükseköğretim programına yerleştirildiği düşünülürse, Y-TM1 puanının 242 243 aralığında olacağı, bu yerleştirme puanı ile İç Anadolu ve Ege bölgelerinde bilinen ve köklü üniversitelerin işletme bölümlerine rahatlıkla yerleşebileceği öngörülmektedir.

Bir başka varsayım ise, YGS'de 20 Türkçe, 15 Sosyal Bilimler neti ile (0 Matematik ve 0 Fen Bilimleri neti), LYS-1 oturumunda 2 Matematik neti, 0 Geometri neti; LYS-3 oturumunda 20 Edebiyat neti ve 7 Coğrafya neti yapan öğrencinin TM-1 puanının $180-181$ aralığında olabileceği; bu adayın en düşük okul başarı puanına sahip olduğu (30 puan) ve bir önceki sene bir yükseköğretim kurumuna yerleşmediği öngörülürse, Y-TM1 puanının 210-211 aralığında olacağı hesaplanabilmektedir. Bu yerleştirme puanı ile Doğu Anadolu 
Bölgesi'ndeki üniversitelerin İşletme bölümlerini rahatlıkla tercih edebileceği öngörülmektedir. Yine aynı adayın bir önceki yıl bir yükseköğretim programına yerleştirildiği düşünülürse, Y-TM1 puanının $195-196$ aralığında olacağı ve bu puan ile yine Doğu Anadolu Bölgesi'ndeki üniversitelerin İşletme bölümüne yerleşebileceği söylenebilmektedir.

Bu varsayımlardan görüleceği üzere 2010 - 2011 yıllarında Türkiye ortalamalarındaki netlere sahip olan bir adayın İ̧̧letme bölümlerine yerleşemediği, 2012'den sonra yerleşme olasılığının arttığı ve gerçekleştiği aşikârdır. 2015 yılında da minimum yapılabilecek netler ile tercih yapılabilmesine olanak tanıyan minimum yeterli yerleştirme puanı ile öğrencilerin İşletme bölümlerine girebilecekleri görülmektedir.

10.11.2015 tarihinde ÖSYM tarafından yayımlanan "2015-ÖSYS Yükseköğretim Programlarının Merkezi Yerleştirmedeki En Küçük ve En Büyük Puanları Kitabı”ndan elde edilen sonuçlara göre işletme bölümüne yerleşen en yüksek puanlı aday 527,396 puana sahiptir. Aynı kaynağa göre, İşletme bölümüne yerleşen en düşük puanlı aday 196,245 puana sahiptir.

Önceki kısımlarda belirtilen tahminleme çalışmasının sonuçlarına göre İşletme bölümüne en düşük yerleşme puanı olarak 195 puan tahminlenmiştir. Yerleşmeye ait gerçek veriler ile bu tahminlemenin örtüştüğü söylenebilmektedir. Bir diğer parametre olan başarı sıralamarına göre ise en iyi başarı sırası 1070, en kötü başarı sırası ise 471000 olarak belirlenmiştir. 2015 yılı içerisinde 17938 adet İşletme bölümüne ait kontenjan açılmıştır. Açılan bu bölüm kontenjanlarının 17472' sinin dolduğu tespit edilmiştir. Buradan hareketle İşletme bölümlerinin 2015 yılı içerisindeki kontenjan doluluk oranının \%97,4 olduğu söylenebilmektedir.

2015 yılı sonuçları önceki yıllara ait sonuçlar ile karşılaştırıldığında çarpıcı bir durum ortaya çıkmıştır. 2015 verilerine göre 196,245 taban puanı 471000 başarı sıralamasına denk gelmektedir. 2014'te ise bu denklik 197,309 taban puanına 437000 olarak görülmektedir. Bu durumda 2015 yılı içerisinde yapılan sınavlarda başarı oranının da düştüğü açıkça görülmektedir ki bu sonuç genel olarak yapılan tahminleme ile örtüşmektedir. Geçrekleştirilen tahminleme çalışmasında analiz yöntemi olarak doğrusal regresyon kullanıımıştır. Bu doğrusal regresyon çalışmasında son beş yıllık ÖSYS verileri kullanılmış olup beş yılın kısa bir dönem ifade etmesinden ötürü tahminlemenin her bir parametre için birebir örtüşmediği gözlenebilmektedir. Ancak başarı sıralamalarının ve taban puanlardaki düşüş trendi ve doluluk oranlarındaki tahminlenen ile gerçek değer arasındaki uyumluluk göze çarpmaktadır.

\section{SONUÇ VE ÖNERILER}

Çalışmada 2010 - 2014 yılları arasında Türkiye'deki devlet üniversitelerindeki işletme bölümlerine ait taban ve tavan puanları, kontenjan sayıları ve doluluk oranları ile minimum ve maksimum başarı sıraları analiz edilmiştir. Bu beş yıllık periyottaki ÖSYM verileri aracılığıyla 2015 yılı için yine aynı değişkenler bazında tahminleme çalışması gerçekleştirilmiş ve sonuçlar paylaşılmıştır. Tahminleme sonucunda elde edilen bulgular, İ̧̧letme bölümündeki ülke genelinde gözlenen düşüşün ilerleyen yıllarda da devam edeceğini öngörmektedir. Bu düşüş hem tavan ve taban puanlar ile başarı sıralarını hem de 
kontenjanların doluluk oranlarını kapsamaktadır. Yani artan kontenjanlar ile birlikte düşen puanlar göz önünde bulundurulduğunda ilerleyen yıllarda daha düşük puan ve geri sıralardaki adayların bile kontenjanını dolduramayacağı bir İşletme bölümünden söz etmek mümkündür. Artan üniversite sayıları ile birlikte birçok bölümde olduğu gibi isşletme bölümünde de görülen kontenjan artışının bölümü tercih eden adayın giderek daha az nitelikli olmasının önüne geçtiği ve buna rağmen yine de $\% 100$ doluluk oranını kaybettiği söylenebilmektedir.

YÖK tarafından 2015 yılında Tıp ve Hukuk Fakülteleri için uygulamaya konacağı açıklanan sabit başarı sıralaması ile Hukuk Fakültesi'ne yerleşemeyen adayların diğer fakülte ve bölümlere yöneleceği, belirtilen bu durumdan İşletme bölümünün de etkileneceği öngörülebilmektedir. Türkiye'nin en köklü bölümlerinden ancak son yıllarda giderek "açıkta kalmamak" için tercih edilen bir bölüm haline gelen İşletme bölümünün geleceği açısından kontenjan sayılarının daha kontrollü belirlenmesi ve Hukuk Fakültesi'ndeki sabit başarı sıralamasına benzer bir uygulamanın İşletme bölümü için de uygulanması olumlu bir adım atılmasını sağlayacaktır.

Önceki kısımlarda belirtildiği üzere beş yıllık verilerin yeterince geniş bir dönem ifade etmemesinden kaynaklı olarak tahminlenen ile gerçekleşen değerler arasında bazı uyumsuzluklar ortaya çıkmıştır. Buradan hareketle sonraki çalışmalarda daha geniş periyotlar ele alınarak ve farklı yöntemlerle tahminleme çalışmaları gerçekleştirilerek daha sağlıklı değerlendirmeler yapmak mümkün olacaktır.

\section{REFERANSLAR}

Çetinsaya, G. (2014). Büyüme, Kalite, Uluslararasılaşma: Türkiye Yükseköğretimi İçin Bir Yol Haritası.

Düzakın, E., Yılmaz, Ö. (2009). İşletme Mezunlarının iş Hayatındaki Yeri ve işletme Eğitimi: 1000 Büyük Sanayi Kuruluşunun İşletme Mezunlarından Beklentileri Üzerine Araştırma. Çukurova Üniversitesi Sosyal Bilimler Enstitüsü Dergisi, 18(1).

Erdoğan, N. (1998). İşletme Yönetiminde Başarının Sırrı:“Üniversite-İ̧ Hayatı İşbirliği”, "2000’li Yıllarda İşletmecilik ve Eğitimi”. Akdeniz Üniversitesi İktisadi ve İdari Bilimler Fakültesi 6. Ulusal İşletmecilik Kongresi Bildiri Kitabı.

Öğrenci Seçme ve Yerleştirme Merkezi. (2010). ÖSYS Öğrenci Seçme ve Yerleştirme Sınavı Yükseköğretim Programları ve Kontenjanları Kılavuzu.

Öğrenci Seçme ve Yerleştirme Merkezi. (2011). ÖSYS Öğrenci Seçme ve Yerleştirme Sınavı Yükseköğretim Programları ve Kontenjanları Kılavuzu.

Öğrenci Seçme ve Yerleştirme Merkezi. (2012). ÖSYS Öğrenci Seçme ve Yerleştirme Sınavı Yükseköğretim Programları ve Kontenjanları Kılavuzu.

Öğrenci Seçme ve Yerleştirme Merkezi. (2013). ÖSYS Öğrenci Seçme ve Yerleştirme Sınavı Yükseköğretim Programları ve Kontenjanları Kılavuzu.

Öğrenci Seçme ve Yerleştirme Merkezi. (2014). ÖSYS Öğrenci Seçme ve Yerleştirme Sınavı Yükseköğretim Programları ve Kontenjanları Kılavuzu. 
Öğrenci Seçme ve Yerleştirme Merkezi. (2015). ÖSYS Yükseköğretim Programlarının Merkezi Yerleştirmedeki En Küçük ve En Büyük Puanları Kitabı.

Patır, S., \& Yıldız, M. S. (2008). İktisadi Ve Idari Bilimler Fakültesi işletme Bölümü Öğrencilerinin Sayısal Derslerdeki Başarııızıı Nedenleri Ve Çözüm Önerileri. Süleyman Demirel Üniversitesi iktisadi ve Idari Bilimler Fakültesi Dergisi, 13(1).

Sargut, A. S. (2009). Türkiye'de işletme yönetimi eğitiminin kurumsal çerçevesi: Çeşitlilikten eşbiçimliliğe. Eskişehir Osmangazi Üniversitesi IïB Dergisi, 4(1), 51-63.

Yelkikalan, N., Pazarcık, Y. (2005). İşletme Eğitiminde Global Perspektif: Çomü Biga ii BF Örneği. Selçuk Üniversitesi Karaman Iktisadi ve İari Bilimler Dergisi, 5(2), 1-20. 